Chapman University

Chapman University Digital Commons

History Faculty Articles and Research

History

8-7-2019

\title{
Planning for a War in Paradise: The 1966 Honolulu Conference and the Shape of the Vietnam War
}

Gregory A. Daddis

Chapman University, daddis@chapman.edu

Follow this and additional works at: https://digitalcommons.chapman.edu/history_articles

Part of the Asian History Commons, Cultural History Commons, Military History Commons, $\underline{\text { Political History Commons, Public History Commons, Social History Commons, and the United }}$ States History Commons

\section{Recommended Citation}

Daddis, Gregory A. "Planning for a War in Paradise: The 1966 Honolulu Conference and the Shape of the Vietnam War ." Journal of Cold War Studies 21, no. 3 (2019): 152-184.

doi: 10.1162/jcws_a_00897

This Article is brought to you for free and open access by the History at Chapman University Digital Commons. It has been accepted for inclusion in History Faculty Articles and Research by an authorized administrator of Chapman University Digital Commons. For more information, please contact laughtin@chapman.edu. 


\section{Planning for a War in Paradise: The 1966 Honolulu Conference and the Shape of the Vietnam War}

\section{Comments}

This article was originally published in Journal of Cold War Studies, volume 21, issue 3, in 2019. DOI:10.1162/

jcws_a_00897

\section{Copyright}

President and Fellows of Harvard College and the Massachusetts Institute of Technology 


\title{
Planning for a War in Paradise
}

\author{
The 1966 Honolulu Conference and the Shape \\ of the Vietnam War
}

$\because \quad$ Gregory A. Daddis

The dust had barely settled on the battlefields along the Ia Drang, a desolate river running through the Central Highlands of South Vietnam (formally known as the Republic of Vietnam, or RVN), when U.S. Secretary of Defense Robert S. McNamara landed in Saigon on 28 November 1965. The brutal fighting between North Vietnamese Army (NVA) regulars and U.S. soldiers from the 1st Cavalry Division had garnered widespread attention back home, a potential harbinger of what an expanding war held in store for the United States. While General William C. Westmoreland lauded the engagement as an "unprecedented victory," McNamara viewed the Ia Drang battles with unease. ${ }^{1}$ American troops had performed well in combat, yet the fighting corroborated intelligence reports of increased enemy infiltration across South Vietnam's porous borders. (In 1965 alone, North Vietnam sent approximately 50,000 soldiers and political cadres down the Ho Chi Minh trail, a key supply route into the embattled South.) Returning to Washington in early December, McNamara detailed for President Lyndon B. Johnson numerous concerns-a "tightly stretched Vietnamese economy," a "government of generals" lacking widespread popular support, and an enemy expected to enlarge its presence inside South Vietnam during the coming year. "The U.S. presence rested on a bowl of jelly," the defense secretary recalled years later. ${ }^{2}$

1. Westmoreland quoted in "Westmoreland Surveys Action," The New York Times, 20 November 1965 , p. 2. Harold G. Moore believed that after the Ia Drang fighting McNamara "now knew the Vietnam War had just exploded into an open-ended and massive commitment of American men, money, and matériel." See Hal Moore and Joseph L. Galloway, We Were Soldiers Once . . and Young (New York: HarperCollins Publishers, 1993), p. 400. See also William Conrad Gibbons, The U.S. Government and the Vietnam War: Executive and Legislative Roles and Relationships, Part IV: July 1965January 1968 (Washington, DC: U.S. Government Printing Office, 1994), pp. 107-108.

2. Robert S. McNamara, In Retrospect: The Tragedy and Lessons of Vietnam (New York: Times Books, 1995), p. 222; and McNamara to Johnson, 7 December 1965, in U.S. Department of State, Foreign

\section{Journal of Cold War Studies}

Vol. 21, No. 3, Summer 2019, pp. 152-184, doi:10.1162/jcws_a_00897

(C) 2019 by the President and Fellows of Harvard College and the Massachusetts Institute of Technology 
Commanders in uniform shared McNamara's worries. Jack Anderson, writing in the Los Angeles Times, could find "no responsible general in the Pentagon who will predict the war will be over within five years, and some of the position papers estimate that jungle fighting will continue for 20 to 30 years." In truth, most top-ranking officers in the U.S. Military Assistance Command, Vietnam (MACV) concurred with the secretary of defense. McNamara and MACV's chief believed American forces had steadied a volatile situation inside South Vietnam-Westmoreland felt they had arrested "the losing trend"- though both acknowledged that military means alone would not achieve the larger political objective of a stable, independent, non-Communist South Vietnam. ${ }^{3}$ The day after McNamara shared his apprehensions with the president, Westmoreland conveyed his guidance to the 1st Infantry Division commander, newly arrived in the RVN. The MACV chief noted that the continuing buildup of allied forces was "providing new and essential resources for the support of rural construction." Moreover, this buildup would permit the release of South Vietnamese units for "clearing and securing operations" so the government of South Vietnam (GVN) could "restore its presence in newly secured areas." An effective rural construction program, Westmoreland concluded, "is essential to our mission." ${ }^{4}$

Two months later, the topics of rural construction and pacification took center stage at a major summit in Honolulu. There, at the Royal Hawaiian Hotel, Westmoreland joined with President Johnson, Secretary of State Dean Rusk, McNamara, key Pentagon officials, and RVN leaders to discuss the expanding war. Johnson hoped to accomplish several aims in Honolulu. Not only would he redirect public attention from nationally televised Senate Foreign Relations Committee hearings on the war, led by an increasingly skeptical (and vocal) Senator J. William Fulbright, but he also intended to limit criticisms of the resumed U.S. bombing of North Vietnam by focusing on

Relations of the United States, 1969-1976, Vol. III, pp. 615-616 (hereinafter referred to as FRUS, with appropriate year and volume numbers). On infiltration numbers, see John Prados, Vietnam: The History of an Unwinnable War, 1945-1975 (Lawrence, KS: University Press of Kansas, 2009), p. 153.

3. Jack Anderson, “20 Years of Fighting in Vietnam?” Los Angeles Times, 24 December 1965, p. A5; and U.S. Grant Sharp and William C. Westmoreland, Report on the War in Vietnam (Washington, DC: U.S. Government Printing Office, 1969), p. 100. McNamara concurred. "We have stopped losing the war," he told the press but conceded it would be a "long war." In Retrospect, p. 222.

4. COMUSMACV, "Increased Emphasis on Rural Construction," 8 December 1965, Correspondence, 1965-1966, in Box 35, Jonathan O. Seaman Papers, U.S. Army Military History Institute, Carlisle Barracks, PA (MHI). For MACV's assessment of South Vietnam's internal troubles in early 1966, see "USMACV Command History," 1966, in Office of Secy, Joint Staff, Mil. Hist. Branch, Entry MACJ03, Box 5, RG 472, National Archives and Records Administration, College Park, Maryland (NARA), pp. 7-8. 
"non-military matters" that would highlight "our pacification efforts and our economic aid." For Johnson, the goal was to demonstrate his commitment to helping the people of South Vietnam "build even while they fight." Moreover, Johnson wanted to assure Chief of State Nguyen Van Thieu and Prime Minister Nguyen Cao Ky the United States would meet its long-term obligations to the RVN. ${ }^{6}$ The highly publicized meetings, however, were more than a political ploy by the shrewd Texas politician. In fact, Honolulu proved to be a key diplomatic session of the U.S. war in Vietnam, at least in the crucial years from 1964 to 1968. During the two-day conference, McNamara and Rusk laid out for MACV's commander a series of objectives, both military and non-military, that would guide the allied war effort through the 1968 Tet Offensive, and even beyond.

A misplaced focus on the public relations aspect of the conference has tended to cloud many historians' judgment of what occurred in Hawaii during the first week of February 1966. Without question, Johnson sought to grab headlines from the Fulbright Committee hearings on the president's request for $\$ 400$ million in supplemental funding for the war. Journalists thus indicated the conference's major purpose was "to lend stature and prestige to the Saigon leaders by giving them a world stage" on which to meet the U.S. president. The Baltimore Sun even summarized Honolulu as "much ado-not much ado about nothing but simply much ado. . . . It was all spectacular and diverting but so far as we can see the problem of the war is where it

5. Johnson-Rusk conversation, 3 February 1966, in FRUS, 1964-1968, Vol. IV, pp. 203-204; Prados, Vietnam, p. 155; and Joseph A. Fry, Debating Vietnam: Fulbright, Stennis, and Their Senate Hearings (Lanham, MD: Rowman \& Littlefield, 2006), pp. 10-11. On the bombing campaign, see Chester L. Cooper et al., "The American Experience with Pacification in Vietnam, Volume II: Elements of Pacification," March 1972, in Folder 65, U.S. Marine Corps History Division, Vietnam War Documents Collection, The Vietnam Archive, Texas Tech University, Lubbock, Texas (TTUVA), p. 160.

6. Lyndon B. Johnson, Public Papers of the President of the United States, 1966, Book I (Washington, DC: U.S. Government Printing Office, 1967), p. 155. On Thieuand Ky, see Graham A. Cosmas, The Joint Chiefs of Staff and the War in Vietnam, 1960-1968, Part 2 (Washington, DC: Office of Joint History, 2012), p. 442; and Robert Dallek, Flawed Giant: Lyndon Johnson and His Times (New York: Oxford University Press, 1998), p. 254. According to Dallek, "Johnson and his aides treated the meeting and its high-minded declarations as realistic solutions for transforming South Vietnam into a stable, popular democracy that could win the war against the Communists" (p. 155).

7. For one of the few works linking the conference in Honolulu to military operations leading up to the high-level meeting, see John M. Carland, United States Army in Vietnam: Stemming the Tide, May 1965 to October 1966 (Washington, DC: Center of Military History, 2000), pp. 155-158. Walt W. Rostow, who became the national security adviser in April 1966, recalled that the Honolulu meeting "was more important than it looked, although less was decided than might have been suspected." He spent only one paragraph, however, on the "necessities" Westmoreland confronted in 1966 and did not evaluate the objectives laid out by Rusk and McNamara. See W. W. Rostow, The Diffusion of Power: An Essay in Recent History (New York: Macmillan, 1972), pp. 452-453. 
was before the burst of activity began." "Historians generally have followed suit, dismissing the conference as a "public relations gimmick." Those who have focused greater attention on the conference's inner workings have suggested that although Johnson paid public lip service to pacification, behind the scenes MACV's commander won endorsement for a strategy based primarily on killing the enemy. Thus, as one recent observer has argued, "the concrete instructions given to Westmoreland in Honolulu made attrition 'the primary operational objective." Despite the rhetoric, pacification "was given short shrift."

A more substantive treatment of the Honolulu conference, however, reveals much more substance than is usually assumed. Far from a presidential scheme to win public support for an escalating and soon to be unpopular war, the Hawaiian summit affirmed allied strategy in South Vietnam for years to come. The goals outlined in the formal memorandum presented to Westmoreland-"a momentous directive," according to one senior officerremained the touchstone of U.S. military operations until superseded in 1969 by a policy of "Vietnamization" under the Nixon administration. ${ }^{10}$ Yet these same objectives suggested a fundamental problem with the U.S. approach to Vietnam. Westmoreland's "momentous directive" contained a dangerous mixture of innocence, arrogance, idealism, and unbounded optimism. Such optimism developed from a definition of strategic success based on U.S. actions rather than on social and political conditions inside South Vietnam. Although

8. Tom Wicker, "Johnson Arrives for Hawaii Talks with Saigon Aides," The New York Times, 6 February 1966, p. 1; Tom Wicker, "Johnson Defends Stand on Vietnam in Hawaii Speech," The New York Times, 7 February 1966, p. 1; and The Baltimore Sun quoted in Senator Mike Gravel, ed., The Pentagon Papers: The Defense Department History of United States Decision Making in Vietnam, 5 vols. (Boston: Beacon Press, 1971-1972), Vol. 2, p. 557. A report on the conference noted that Johnson hoped to "increase U.S. public support of the Administration's Vietnam policy." See "Presidential Decisions: The Honolulu Conference, February 6-8, 1966," in Folder 2, Box 4, Larry Berman Collection (Presidential Archives Research), TTUVA, p. 10. The U.S. Army's official history also suggests that President Johnson intended the conference to "dilute the impact of Fulbright's investigation." William M. Hammond, United States Army in Vietnam: Public Affairs: The Military and the Media, 1962-1968 (Washington, DC: Center of Military History, 1988), p. 247.

9. George C. Herring, LBJ and Vietnam: A Different Kind of War (Austin: University of Texas Press, 1994), p. 68; Jonathan D. Caverley, "Explaining U.S. Military Strategy in Vietnam," International Security, Vol. 35, No. 3 (Winter 2010/2011), p. 130; and Jonathan D. Caverley, "The Myth of Military Myopia: Democracy, Small Wars, and Vietnam," International Security, Vol. 34, No. 3 (Winter 2009/2010), p. 130. Bernard B. Fall believed that President Johnson, by going to Honolulu and meeting with South Vietnamese leaders, had "committed the prestige of his office not only to the continued support of the southern regime, but to that of its leaders as well." See Bernard B. Fall, "Vietnam: The Quest for Stability," Current History, Vol. 52 (January 1967), p. 9.

10. Phillip B. Davidson, Vietnam at War: The History: 1946-1975 (Novato, CA: Presidio, 1988), p. 359. For a treatment of the relationships between military leaders and the White House during the Nixon years, see Gregory A. Daddis, Withdrawal: Reassessing America's Final Years in Vietnam (New York: Oxford University Press, 2017). 
senior U.S. officials acknowledged that ultimate success depended on local entities, they presumed — on little more than faith alone — that they could set the conditions for that success. ${ }^{11}$ The failure of these officials to consider the limits of U.S. power abroad not only helps explain the outcome in Vietnam but offers a cautionary tale for present policy challenges seemingly demanding U.S. intervention overseas.

\section{A War Requiring More than War}

In early January 1966, Secretary of State Rusk dispatched an urgent telegram to the U.S. embassy in Saigon stressing that the president was "most anxious to show in every possible way our concern for peaceful development and progress of SVN [South Vietnam] and our emphasis on non-military measures." Johnson was serious about the role of development. "I want to have a war that will build as well as destroy," he exclaimed to Robert Komer, soon to be named head of the U.S. pacification effort. The focus on nation-building in the RVN, however, long preceded the Johnson administration. Since the division of Indochina at the 1954 Geneva summit, U.S. officials had wrestled with the problems of building a viable, non-Communist state in the South. Michigan State University fielded an advisory group in 1955 that counseled South Vietnamese administrators and civic leaders on topics ranging from public information and finance to building a transportation and communication infrastructure. ${ }^{12}$ Wesley R. Fishel, a political scientist at Michigan State, suggested two "salient facts" influenced South Vietnamese politics: "violent subversive activity of the Communists" and the country's "achievements in the economic and social fields." Even the head of the U.S. military advisory

11. Dallek in Flawed Giant, p. 358, suggests that the "hopes of the Honolulu declarations rested on illusions that could not withstand conditions in South Vietnam." Thus, the conference seemed to accord with what one contemporary correspondent deemed the "American experience in Vietnamoptimism followed by disappointment and frustration." See Charles B. Flood, The War of the Innocents (New York: McGraw-Hill Book Company, 1970), p. 192.

12. Rusk memorandum, 4 January 1966, in FRUS, 1964-1968, Vol. IV, p. 14. Rusk recalled the difficulties of nation-building in a time of war. "It isn't easy to improve education and improve agriculture and restrain inflation and do all these things in the middle of a war, particularly a guerrilla-type war which subjected the government structure in the countryside to continued harassment. It's hard to build schools when schoolteachers are being assassinated." Dean Rusk, interview by Paige E. Mulhollan, 2 January 1970, in Oral History Collection, Lyndon Baines Johnson Presidential Library, Austin, Texas (LBJL). Johnson quoted in Lloyd C. Gardner, Pay Any Price: Lyndon Johnson and the Wars for Vietnam (Chicago: Ivan R. Dee, 1995), p. 298. On MSUG, see James M. Carter, Inventing Vietnam: The United States and State Building, 1954-1968 (New York: Cambridge University Press, 2008), p. 49. 
group maintained that military operations alone were insufficient. Although General Samuel T. Williams worried about the military threat posed by both conventional and guerrilla forces, he acknowledged that the government must embrace "political, psychological, economic, administrative, and military action" to be successful. ${ }^{13}$

Amid the social and political unrest in South Vietnam, however, such aspirations were difficult to realize. President Ngo Dinh Diem, an ardent nationalist and anti-Communist, struggled to build a durable state in the aftermath of an eight-year war with France. Capable administrators were in short supply. Agrarian reform measures reaped only modest gains in uniting those living across the rural countryside. The seeds of a growing insurgency movement already were taking root. Perhaps most importantly, Diem confronted an ultimately intractable problem—gaining legitimacy among and establishing governmental control over a population distrustful of the Saigon regime. ${ }^{14}$ Although Diem aspired to engineer a social revolution inside South Vietnam, he too often (though by some estimates, necessarily) focused his attention on internal "security matters." U.S. critics bemoaned what they saw as the increasingly brutal tactics of a police state. Ambassador Elbridge Durbrow, writing in 1957, complained of the RVN president's "suspiciousness and authoritarianism" and concluded that the "base of the regime's popular support remains narrow." ${ }^{15}$ Senior U.S. officials clearly understood the difficulties of intervening in Southeast Asia yet presupposed their capacity (and wherewithal) to participate successfully in nation-building efforts overseas.

If U.S. officials viewed skeptically their South Vietnamese allies' conceptions of nationhood in the modern era, they did so through the lens of New Deal-era reforms. Most U.S. aid officials saw in Franklin Roosevelt's liberal

13. Wesley R. Fishel, "Political Realities in Vietnam," Asian Survey, Vol. 1, No. 2 (April 1961), p. 15; and Williams memorandum, 28 December 1955, in FRUS, 1955-1957, Vol. I, p. 608. On Williams's focusing on more than just military matters, see also Briefing Charts, Personal Use of Lt. General S. T. Williams, 31 May 1957, in Conversations with President Diem Folder, Box 3, Samuel T. Williams Papers, MHI.

14. Wolf I. Ladejinsky, "Agrarian Reform in the Republic of Vietnam," in Wesley R. Fishel, ed., Problems of Freedom: South Vietnam since Independence (New York: The Free Press of Glencoe, 1961), pp. 153-173. On Diem, see Edward Miller, Misalliance: Ngo Dinh Diem, the United States, and the Fate of South Vietnam (Cambridge, MA: Harvard University Press, 2013), pp. 87, 171. For an assessment of the political situation in Saigon at the time of the Honolulu conference, see David Marr, "Political Attitudes and Activities of Young Urban Intellectuals in South Viet-Nam," Asian Survey, Vol. 6, No. 5 (May 1966), pp. 249-263.

15. Durbrow quoted in Robert Mann, A Grand Delusion: America's Descent into Vietnam (New York: Basic Books, 2001), p. 212. On Diem's problems, see pp. 179, 184. For a more sympathetic treatment of Diem, see Mark Moyar, Triumph Forsaken: The Vietnam War, 1954-1965 (New York: Cambridge University Press, 2006). 
policy agenda an archetype for economic and political progress abroad. Thus, advocates of "high modernism" believed in government's ability to fund and administer massive aid projects that would modernize underdeveloped countries and, in due course, promote economic dividends and political constancy. Rural democracy, electrification, and agricultural programs all went hand in hand. ${ }^{16}$ No wonder, then, that in April 1965, in a major speech on Vietnam at Johns Hopkins University, President Johnson cited the most ambitious of New Deal programs, the Tennessee Valley Authority (TVA) hydroelectricity project. "The vast Mekong Delta can provide food and water and power on a scale to dwarf even our own TVA," Johnson declared. In the same speech, the president spoke about the "wonders of modern medicine," the establishment of schools to "train people in the skills needed to manage the process of development," and the effort "to replace despair with hope and terror with progress." As if to demonstrate resolve in assisting with the RVN's social revolution, Johnson brought with him to Honolulu in 1966 Secretary of Agriculture Orville Freeman and Secretary of Health, Education, and Welfare John Gardner. ${ }^{17}$

Carrying forward the legacy of New Deal reformers, U.S. aid officials and technical experts traveling to Vietnam in the late 1950s and early 1960s hardly questioned the underlying assumptions on which modernization theories rested. To these interventionists, the Allied victory in 1945 had left a dangerously unpredictable world in its wake, while the subsequent anti-colonial struggles in Africa and Asia called for long-term solutions to global instability. ${ }^{18}$ The rising threat of Communism did little to assuage fears of perpetual dangers abroad. Yet modernization theory was far more than a response to

16. Miller, Misalliance, pp. 56-58; Gabriel Kolko, Anatomy of a War: Vietnam, the United States, and the Modern Historical Experience (New York: Pantheon Books, 1985), p. 237; and Fishel, "Political Realities in Vietnam," p. 20. There were, of course, deficiencies undergirding the latent "economic man" logic Walt Rostow's stages of development model. Not all local leaders saw the United States as the apogee of political thought and systems. See W. W. Rostow, The Stages of Economic Growth: A Non-Communist Manifesto (New York: Cambridge University Press, 1960).

17. Johnson speech in Robert J. McMahon, ed., Major Problems in the History of the Vietnam War, 2nd ed. (Lexington, MA: DC Heath, 1995), p. 213; and Cooper et al., "The American Experience with Pacification in Vietnam," p. 223. Secretary Freeman, who went to the RVN after the conference, recalled that the South Vietnamese government was "very cooperative," but he never got "down to the nuts and bolts implementation where the real problems would reside."See Orville Freeman, interview by T. H. Baker, 21 July 1969, in Oral History Collection, LBJL.

18. On the origins of modernization theory, see Dean C. Tipps, "Modernization Theory and the Comparative Study of Societies: A Critical Perspective," Comparative Studies in Society and History, Vol. 15, No. 2 (March 1973), pp. 200-210; and Michael E. Latham, "Redirecting the Revolution? The USA and the Failure of Nation-Building in South Vietnam," Third World Quarterly, Vol. 27, No. 1 (2006), pp. 28-32. 
Cold War Communism. It promised a way to create nation-states and national identities, a progression through which backward states could grow and become more modern, more American in body as well as outlook. In the process, traditional loyalties to families and communities, invariably susceptible to Communist subversion, modernizers supposed, could be transferred to the enlightened nation. Here was a way to link individuals to new, democratic social structures that would participate in a larger (U.S.-aligned) global community. ${ }^{19}$ Putting theory into practice, however, required a laboratory, and Southeast Asia seemed an appropriate test case for building dynamic, rational, modern nations while combating Communism overseas. When Johnson recalled after his presidency that he wanted to "develop democratic forms" in the "young Asian country" of South Vietnam, he spoke in terms easily recognizable to modernization theorists. ${ }^{20}$

If progressive foreign policy advocates agreed on the outcome for a modern, democratic RVN, they fiercely debated how best to achieve social and economic progress, and thus long-term governmental stability, in a regime contending with both an external threat from the north and a growing insurgency within its own borders. Few agreed how to shepherd South Vietnam from a "traditional" to a "modern" society. While high modernists advocated a centrally planned, technologically driven approach, low modernists encouraged decentralization and local aid programs. ${ }^{21}$ In the process, U.S. officials too often failed to ask the South Vietnamese themselves which methods most suited their needs. As with so many social science models, modernization theory, according to Mark T. Berger, held "little or no regard for questions of time and place" and undermined existing relationships "to the temporal and spatial specificity of the formation, consolidation or collapse of new nationstates." Moreover, theoretical models hardly took into account the competing ideologies permeating South Vietnamese society in the late 1950s and early

19. On national identities, anti-Communism, and traditional loyalties, see Mark T. Berger, "Decolonisation, Modernisation and Nation-Building: Political Development Theory and the Appeal of Communism in Southeast Asia, 1945-1975," Journal of Southeast Asian Studies, Vol. 34, No. 3 (October 2003), pp. 422, 429, 435. On social structures, see Miller, Misalliance, p. 66.

20. Lyndon Baines Johnson, The Vantage Point: Perspectives on the Presidency, 1963-1969 (New York: Holt, Rinehart and Winston, 1971), p. 242. Less than two years after Honolulu, Charles A. Joiner found that the "nation-building procedures of 1967, even when combined with definite military advances, did not permeate the underlying sources of Saigon's difficulties." See Charles A. Joiner, "South Vietnam: Political, Military and Constitutional Arenas in Nation Building," Asian Survey, Vol. 8, No. 1 (January 1968), p. 71.

21. Miller, Misalliance, pp. 66-68; Carter, Inventing Vietnam, p. 35; and Christopher T. Fisher, "The Illusion of Progress: CORDS and the Crisis of Modernization in South Vietnam, 1965-1968," Pacific Historical Review, Vol. 75, No. 1 (February 2006), p. 36. 
1960s. This was no clean slate on which U.S. technicians and political scientists could work their magic. In the end, only local leaders and the people of South Vietnam could ascertain (and achieve) the proper balance between tradition and modernity. ${ }^{22}$

To most U.S. officials considering the problem of nation-building in Southeast Asia, one local condition appeared to rank highest among numerous, often competing, priorities: Modernization could occur only in a secure environment. Counterinsurgency enthusiasts and senior officers chomped at the bit to prove the worth of military means in promoting government stability and, ultimately, American-inspired democracy. History seemed to validate their claims. Retired four-star general and U.S. ambassador to the RVN Maxwell D. Taylor warned of

trying too much in the civil field before an adequate level of security was reached. We should have learned from our frontier forebears that there is little use of planting corn outside the stockade if there are still Indians around in the woods outside. $^{23}$

Weeks before the Honolulu conference, David E. Bell, administrator of the United States Agency for International Development (USAID), struck a similar chord. Bell defined "pacification" as a process that began with sweeping enemy military units from an area, establishing "local security against terrorism," and then fostering "effective institutions of local government." Few if any critics questioned this sequential process of nation building. In what would become a popular portrayal of U.S. Army operations in Vietnam, Bell suggested that a "steady widening of . . . 'pacified' areas" could be achieved only "behind the shield of military protection." No matter that, in the process, the visibility Johnson hoped to place on economic and social development might be diminished. ${ }^{24}$

22. Berger, "Decolonisation, Modernisation and Nation-Building," p. 423; and Neil L. Jamieson, Understanding Vietnam (Berkeley: University of California Press, 1993), pp. 99, 257. For a fine overview of the war from the South Vietnamese perspective, a war viewed as one of "competing visions" for Vietnam's future, see Mark Philip Bradley, Vietnam at War (New York: Oxford University Press, 2009).

23. Maxwell D. Taylor, Swords and Plowshares (New York: W. W. Norton, 1972), p. 340. Miller, Misalliance, p. 82. On tensions between security and reform in contemporary debates over how best to defeat insurgency movements, see Larry E. Cable, Conflict of Myths: The Development of American Counterinsurgency Doctrine and the Vietnam War (New York: New York University Press, 1986), p. 192.

24. Bell to Johnson, 19 January 1966, in FRUS, 1964-1968, Vol. IV, p. 85; and Fisher, "The Illusion of Progress," p. 41. Military officers spoke in similar terms. In November 1965, a few months before the Honolulu conference, Marine General Lewis Walt wrote Westmoreland that he understood his "primary mission" was to "provide a security shield behind which the ARVN can develop a reliable 
In the summer of 1965, MACV's commander followed a similar sequential approach to security and development when crafting his own concept of operations for allied forces in the RVN. Westmoreland emphasized the need to provide security to the population, both from large, well-equipped forces looming outside the country and from "the guerrilla, the assassin, the terrorist, and the informer." To the general, only the South Vietnamese Army $(\mathrm{ARVN})$ could make "real progress and succeed" against the latter threats. ${ }^{25}$ In September, Westmoreland elaborated his concept further in a directive to his subordinate commanders. After cautioning his leaders to make a conscious effort to "minimize battle casualties among those noncombatants who must be brought back into the fold" of government control, the MACV chief underscored his larger goals. The "ultimate aim is to pacify the Republic of Vietnam by destroying the VC [Vietcong] ... while at the same time reestablishing the government apparatus, strengthening GVN military forces, rebuilding the administrative machinery, and re-instituting the services of the Government." This was an extremely tall order, one that would test the limits of U.S. influence abroad. Westmoreland's strategic concept, however, rested on similar assumptions displayed at Honolulu. Not only did most U.S. policymakers and military leaders take for granted their ability to keep the enemy "off balance"; they also accepted, despite the difficulties they surely would face, their capacity to build functioning nation-states even in the midst of brutal civil wars. ${ }^{26}$

Westmoreland's notion that U.S. military operations should set the foundation for RVN pacification and civic action accorded well with contemporary literature and U.S. Army doctrine. Writing in 1964, French military theorist David Galula outlined a blueprint for a general "strategy" of counterinsurgency. Following a "step-by-step procedure," the counterinsurgent was first to destroy the main body of armed insurgents before establishing contact with the population and then educating the leaders in a "national political

rural construction program." See Walt to Westmoreland, 19 November 1965, in Folder 7, Box 2, Official Correspondence, Series I, W. C. Westmoreland Collection, MHI.

25. Concept of Operations, 13 June 1965, The Pentagon Papers, Vol. IV, pp. 606-608. For a comparison to Westmoreland's approach one year later, see "Concept of Military Operations in South Vietnam," 26 August 1966, in Folder 3, Box 5, Larry Berman Collection (Presidential Archives Research), TTUVA.

26. Westmoreland directive to U.S. commanders, 17 September 1965, in Michael H. Hunt, ed., $A$ Vietnam War Reader: A Documentary History from American and Vietnamese Perspectives (Chapel Hill: University of North Carolina Press, 2010), pp. 89-90. For a fuller discussion of U.S. strategy, see Gregory A. Daddis, Westmoreland's War: Reassessing American Strategy in Vietnam (New York: Oxford University Press, 2014). 
movement. ${ }^{\prime 27}$ Laying aside the dubious claim that counterinsurgency was indeed a strategy, Galula's methodical, and thus accessible, approach to defeating insurgent movements appealed to U.S. Army officers heading off to Vietnam. The French officer's ideas were far from exceptional. American John J. McCuen encouraged a similar methodology in The Art of CounterRevolutionary Warfare, published the same year as the Honolulu conference. Discussing the topic of civic action, McCuen, a lieutenant colonel, maintained that the "destruction of the revolutionary organization must be followed by construction of a counter-revolutionary substitute." Military and police action would first "break the hold of the terrorists on the population," before civic action teams followed with a construction plan to gain "close person-toperson contact with the population." No surprise then that the April 1965 Advisor Handbook for Counterinsurgency, a U.S. Army doctrinal pamphlet, spoke of "clear and hold" operations to create a secure physical environment before establishing firm governmental control and "willing support of the population." 28

The November 1965 battles along the Ia Drang should be considered within this theoretical and doctrinal context. Shielding the population required the allies to combat two types of enemy threat-conventional units infiltrating from North Vietnam and insurgent forces from within the RVN's borders. Counterinsurgency alone would not shield the population, a point stressed by Westmoreland. Thus, the 1965 fighting in the Central Highlands exemplified MACV's justifiable concerns over porous borders between South Vietnam and Cambodia and Laos. Counterinsurgency operations made little sense against the three North Vietnamese regiments concentrating in Pleiku Province and aiming to spearhead an offensive that would cut deeply into the RVN by controlling the crucial Highway $19 .{ }^{29}$ To the MACV commander, no pacification effort could succeed if these main force units remained

27. David Galula, Counterinsurgency Warfare: Theory and Practice (New York: Frederick A. Praeger, 1964), p. 80. For a more critical review of Galula's work, see Grégor Mathias, Galula in Algeria: Counterinsurgency Practice versus Theory, trans. by Neal Durando (Santa Barbara, CA: Praeger, 2011).

28. John J. McCuen, The Art of Counter-Revolutionary War: The Strategy of Counterinsurgency (St. Petersburg, FL: Hailer Publishing, 2005), p. 152; and U.S. Department of the Army, Advisor Handbook for Counterinsurgency, Field Manual 31-73 (Washington, DC: U.S. Government Printing Office, April 1965), p. 58.

29. On the battle's larger strategic setting, see George C. Herring, "The 1st Cavalry and the Ia Drang Valley, 18 October-24 November 1965," in Charles E. Heller and William A. Stofft, eds., America's First Battles, 1776-1965 (Lawrence, KS: University Press of Kansas, 1986), pp. 308-316. On why MACV's operational approach made sense, see Dale Andrade, "Westmoreland Was Right: Learning Wrong Lessons from the Vietnam War," Small Wars \& Insurgencies, Vol. 19, No. 2 (June 2008), pp. 145-181. 
free to roam the countryside and strike population centers at will. Despite the successful fighting along the Ia Drang, these concerns hardly dissipated in 1966. Charles Mohr, a correspondent for The New York Times, reported on the eve of the Honolulu conference that there were "now 230,000 to 250,000 pro-Communist troops in South Vietnam, including Vietcong guerrillas and about 11 tough regiments of the North Vietnamese Army." According to Mohr, that was "at least twice as many enemy troops as there were at the start of last year, despite the major United States build-up since then." 30

However, the mushrooming of enemy troops inside the RVN did not prevent senior U.S. officials from considering the conflict's nonmilitary aspects. In fact, by December 1965 most U.S. policymakers admitted that Operation Rolling Thunder, the strategic bombing campaign against North Vietnam, was failing to persuade Hanoi's leaders not to support the southern insurgency. ${ }^{31}$ By the new year, almost all U.S. military personnel were emphasizing the need for more than just military operations. Westmoreland called for “'complete integration' of all U.S. programs, military and civilian, that were involved in pacification." David Bell, returning from an early January trip to Vietnam, told the president and the National Security Council (NSC) staff that the "Number one problem is rural pacification." ${ }^{32}$ Two weeks later, McNamara wrote Johnson that deploying additional U.S. forces would facilitate several objectives: permitting control of critical roads and railways, increasing government control over the population, destroying enemy base areas, and "attriting" enemy forces at an increased rate. Even with these additional deployments, McNamara concluded that the "odds are about even" whether the allies would face a stalemate in early $1967 .{ }^{33}$ The goals outlined in this late January memorandum to the president mirrored those drafted at the Honolulu conference the following month. That they gave the United States

30. Charles Mohr, "The Honolulu Agenda," The New York Times, 7 February 1966, p. 6; and William C. Westmoreland, A Soldier Reports (Garden City, NY: Doubleday, 1976), pp. 189-190. On Westmoreland seeing the "reinstitution of governmental services and activities" as closely linked with military operations, see MACV Directive 525-4, "Tactics and Techniques for Employment of U.S. Forces in the Republic of Vietnam," 17 September 1965, in Vietnam Tactics \& Techniques in Country Publications Folder, Historian's Files, U.S. Army Center of Military History (CMH), Fort McNair, Washington, DC.

31. The Pentagon Papers, Vol. 4, pp. 53-54.

32. Westmoreland and Bell quoted in Gibbons, The U.S. Government and the Vietnam War, p. 185. For an alternative perspective, see Merle L. Pribbenow II, "Rolling Thunder and Linebacker Campaigns: The North Vietnamese View," The Journal of American-East Asian Relations, Vol. 10, No. 3/4 (FallWinter 2001), pp. 197-210.

33. McNamara to Johnson, 14 January 1966, in FRUS, 1964-1968, Vol. IV, pp. 115-117. For a contemporary critique of U.S. strategy, see Stanley Karnow, "Despite Staggering Commitment, Goals Appear Clouded in Saigon," The Washington Post, 3 February 1966, p. A6. 
only a 50-50 chance of success suggested grave inadequacies with the strategic approach to the war in Vietnam.

\section{Setting American Goals in Hawaii}

"Tonight the cup of peril is full in Vietnam." So remarked President Johnson in his State of the Union address to Congress on 12 January 1966. Although the president's rhetorical flourish struck an alarmist tone, the brewing war in Southeast Asia seemed to warrant heightened anxiety. A 37-day bombing pause over North Vietnam had failed to spur progress in peace negotiations, instead garnering fiery debate at home over U.S. strategy and political aims. House Armed Services Committee Chairman L. Mendel Rivers warned that the war "was getting very unpopular the way we are conducting it." ${ }^{44} \mathrm{On}$ 3 February, the Senate Foreign Relations Committee agreed to hold public hearings on Vietnam. Senator Fulbright hoped the hearings would "inform the American people ... as fully as possible about the implications of the war in Vietnam," especially in light of the president's request for $\$ 12.7$ billion in supplemental funds. Senator Wayne L. Morse more bluntly declared the televised inquiry would force the White House "out in the public." The following day, committee members began questioning USAID's Bell. Johnson, sensing the shifting political landscape, took the offensive. Even as administration officials were being grilled by Fulbright's committee, television newscasters interrupted their networks' coverage of the hearings to announce that Johnson was departing the next day for a major summit in Hawaii to meet with RVN leaders. $^{35}$

Though hastily convened, the conference in Honolulu proved more than a simple redirection of television cameras. With the failure of the bombing pause, Johnson believed it crucial to reinforce his commitment to inaugurating "certain pacification programs in the fields of health, education, and agriculture in Vietnam." During the welcoming ceremony at Honolulu

34. Johnson, Public Papers of the President of the United States, p. 7. Rivers quoted in Dallek, Flawed Giant, p. 351. On the bombing pause, see Wallace J. Thies, When Governments Collide: Coercion and Diplomacy in the Vietnam Conflict, 1964-1968 (Berkeley: University of California Press, 1980), p. 127.

35. Fulbright and Morse quoted in Fry, Debating Vietnam, p. 31; and Gibbons, The U.S. Government and the Vietnam War, pp. 222, 230. See also Randall B. Woods, "Dixie's Dove: J. William Fulbright, the Vietnam War, and the American South," in Randall B. Woods, ed., Vietnam and the American Political Tradition: The Politics of Dissent (New York: Cambridge University Press, 2003), pp. 149_ 170 . 
International Airport, the president declared that he had come to "talk of our resolution to defend peace and to build a decent society for the people of South Vietnam." Prime Minister Ky, sharing the spotlight with Thieu, concentrated on four points during his speech: "defeating the Vietcong, eradicating social injustice, establishing a viable economy, and building true democracy." ${ }^{36}$ No doubt these intentions met with favor among the U.S. cohort, yet Johnson pressed the South Vietnamese leaders further at a private meeting on 7 February. Showing little appreciation of the revolutionary struggle inside the RVN, Johnson urged Ky and Thieu to "develop better contacts with the VC in order to gain increased understanding of the movement." The exhortation likely baffled both men, who surely comprehended the underlying principles and political reach of the National Liberation Front. Still, Westmoreland believed Ky and Thieu were grateful, not only for the moral and physical support provided by Johnson but also because "they were treated with dignity as an ally." ${ }^{37}$

The initial press reactions highlighted Johnson's attempt, in his first trip outside the North American continent as president, to lend stature to the South Vietnamese authorities. Yet, although domestic support for the war remained reasonably high, some journalists questioned the president's hopes for stimulating political and economic progress abroad. The Christian Science Monitor suggested that failure had sent Johnson to Hawaii, "the failure of American democracy to touch the Asian people it is defending and to change the down-trodden condition of their lives." Tom Wicker of The New York Times observed the president's trip was "seeking to take away headlines—and possible witnesses-from the televised inquiry of the Senate Foreign Relations Committee." (Indeed, Fulbright protested wartime executive commitments without congressional consideration or approval. $)^{38}$ Nonetheless, almost all

36. Nguyen Cao Ky with Marvin J. Wolf, Buddha's Child: My Fight to Save Vietnam (New York: St. Martin's Press, 2002), p. 186; Johnson, Public Papers, p. 151; and "Presidential Decisions: The Honolulu Conference, February 6-8, 1966," p. 18. Under Secretary of State George Ball, for his part, "viewed the whole idea of a conference as being absolutely appalling because I was convinced that the President got out there with whoever happened to be the head of the government in Vietnam, and we were going to get in deeper and deeper and deeper." See George Ball, interview by Paige E. Mulhollan, 8 July 1971, in Oral History Collection, LBJL.

37. Moyers to Johnson, 12 February 1966, in FRUS, 1964-1968, Vol. IV, p. 227; and William C. Westmoreland, interview by Paul L. Miles, 7 January 1971, in Box 1, Paul L. Miles Papers, MHI, p. 4.

38. Saville R. Davis, "Johnson Pursues Vietnam Reforms," The Christian Science Monitor, 7 February 1966, p. 1; Wicker, "Johnson Arrives for Hawaii Talks with Saigon Aides," p. 1; and Wicker, "Johnson Defends Stand on Vietnam in Hawaii Speech," p. 1. For a more positive view, see "A Change of Emphasis in the Vietnam War?" The Hartford Courant, 8 February 1966, p. 18. Business Week trumpeted that at Honolulu Johnson "abruptly switched the emphasis in the Vietnam war from military action 
media outlets took notice of Johnson's emphasis on the non-military aspects of the war. Westmoreland did his part as well. The day before Johnson arrived in Honolulu, the MACV commander held a press conference at the Royal Hawaiian Hotel warning of a long war that would not be "concluded by a single battle or campaign." Westmoreland then noted that, concurrent with any military operations, the GVN would be pursuing rural construction and pacification programs. Once enemy forces were destroyed, the government could "move forward in improving the lot of the people through civic action, to include military aid, construction of dispensaries, maternity wards, schools ... and programs to improve their agriculture and the general productivity of the country." ${ }^{39}$

These public pronouncements mirrored private meetings, especially between U.S. policymakers and military leaders. Even though Johnson stressed at the plenary session's conclusion that he wanted MACV's commander to "nail the coonskin to the wall"-Westmoreland recalled that the wartime president was "looking for success" - he still pressed his advisers behind closed doors on nonmilitary action. Without question, Johnson's reluctant approval of an increase in U.S. troop strength to 440,000 men by the end of 1966 suggested his commitment to fighting across the breadth of the RVN. ${ }^{40}$ Yet the conference proceedings also demonstrated a genuine commitment to what increasingly would become dubbed "the other war," a phrase referring to allied pacification plans. The U.S. delegation examined internal RVN programs, covering topics from village council elections to troop indoctrination programs, from land reform to care of refugees. Secretary of State Rusk led discussions on measures "to increase pressure on Hanoi to bring them to the conference table." Health and Education Secretary Gardner covered the training of health personnel and the building of effective medical logistics systems, and Agriculture Secretary Freeman assessed food and fertilizer production programs and experimentation with new strains of rice, corn, and

to works of peace." See "Adding Social Reform to Vietnam Arsenal," Business Week, 12 February 1966, p. 27. On congressional oversight, see Fry, Debating Vietnam, p. 116.

39. Cooper et al., "The American Experience with Pacification in Vietnam," pp. 3, 6. For a contemporary critique of this approach, one that saw a disparity between concept and practice, see Ray Cole Hillam, "What Guns, Bombs, and Lives Have Not Purchased: The Frustration of Vietnam," Brigham Young University Studies, Vol. 8, No. 1 (Autumn 1967), pp. 47-59.

40. Westmoreland, interview by Miles, p. 1. Johnson's "coonskin" comment is reported in Larry Berman, "From Intervention to Disengagement: The United States in Vietnam," in Foreign Military Intervention: The Dynamics of Protracted Conflict (New York: Columbia University Press, 1992), p. 43. On troop strength increases, see Prados, Vietnam, p. 151; and Edward J. Drea, McNamara, Clifford, and the Burdens of Vietnam, 1965-1969 (Washington, DC: Office of the Secretary of Defense Historical Office, 2011), p. 123. 
vegetable seeds. ${ }^{41}$ These multiple tracks of inquiry, far from a media relations ruse, in fact cohered around the basic foundation of U.S. military strategy established by Westmoreland the previous summer.

The MACV commander's meetings with the president, defense secretary, and representatives from the Joint Chiefs of Staff (JCS) further revealed a dedication to advancing a comprehensive plan for the political-military war inside the RVN. Westmoreland described a "formidable task" ahead, reiterating his belief that the allies "were not going to turn the tide in any single battle or campaign." In this war, the general advised, "physical and psychological factors were closely related." ${ }^{\prime 2}$ As during the previous summer's debate over committing U.S. ground combat troops to Vietnam, much of the discussion in Honolulu revolved around the forecasting and resourcing of U.S. deployment numbers. (The JCS harped on a familiar theme-pressing Johnson, unsuccessfully, to authorize a call-up of reserve forces.) Westmoreland, however, wanted Johnson to grasp the difficulties that lay ahead. MACV still had to establish a sound logistical system while reorienting the South Vietnamese armed forces toward the difficult tasks of rural construction and pacification. The general also explained that the ARVN was "very young and that its leadership was quite mediocre." ${ }^{43}$ Although the president recalled gaining a "better understanding of the problems we faced and of what needed to be done to make progress," the conference at Honolulu proved unsettling for him. Toward the end of one meeting with Westmoreland, he cautioned the MACV commander. "There's a lot riding on you. I don't expect you to let me down." Adding a finer point, a fatigued Johnson, alluding to frayed civil-military relations during the Korean War, warned, "I hope you don't pull a MacArthur on me." ${ }^{44}$

41. Bundy memorandum, 23 February 1966, in FRUS, 1964-1968, Vol. IV, pp. 246-255. On the consequences of this focus on agricultural output, see Simon Toner, "The Life and Death of Our Republic': Modernization, Agricultural Development and the Peasantry in the Mekong Delta in the Long 1970s," in Leslie James and Elisabeth Leake, eds., Decolonization and the Cold War: Negotiating Independence (London: Bloomsbury, 2015).

42. Westmoreland, interview, in MHI, p. 1. The general spoke in similar terms in his long-range planning for 1967. See Westmoreland to Admiral Sharp and General Wheeler, CJCS, "Strategy and Concept of Operations for 1967," 11 December 1966, in U.S. Strategy, Vietnam Folder, Historian's Files, $\mathrm{CMH}$.

43. Westmoreland interview, p. 5; The Pentagon Papers, Vol. 4, pp. 311-314; and Cosmas, The Joint Chiefs of Staff and The War in Vietnam, p. 442. On building South Vietnam's armed forces, see James Lawton Collins, Jr., The Development and Training of the South Vietnamese Army, 1950-1972 (1975; Washington, DC: U.S. Government Printing Office, 2002).

44. Johnson, The Vantage Point, p. 243; Westmoreland, interview, p. 8; Westmoreland, A Soldier Reports, p. 193; and Samuel Zaffiri, Westmoreland: A Biography of General William C. Westmoreland (New York: William Morrow, 1994), pp. 159-160. 
Whether admonition or expression of confidence (Westmoreland believed the latter), Johnson's warning arguably revealed underlying anxieties about the war's trajectory. Still hoping to limit the conflict and concentrate on his domestic agenda, the president saw in Hawaii the mounting sacrifices that would be needed to contain Communism throughout the RVN. Building a legitimate political system centered on Saigon potentially meant years of effort. Yet despite warning signs - the failure of the bombing campaign over North Vietnam and the continued political instability within the GVN-Johnson pressed forward. ${ }^{45}$ Though difficulties surely lay ahead, Westmoreland had stemmed the tide and, at least for the moment, had stabilized the military situation. A comprehensive plan incorporating both military and nonmilitary programs might well see the allies through and convince the leaders in Hanoi that their war was unwinnable. Accordingly, the Honolulu conference produced two major allied objectives: to defeat Vietcong and North Vietnamese Army forces and compel their withdrawal from the South; and to "extend GVN dominion, direction, and control" over South Vietnam. In the process, U.S. units assisted South Vietnamese forces in "clearing and securing the civic action operations." Although offensive battles and campaigns were not part of the rural construction effort, they were "constituted concomitantly with it." The prime focus of combat-capable units, senior military officers at Pacific Command concluded, "must be directed to the search and destroy effort." 46

The phrase "search and destroy" has long been equated with military ineptitude and even outright malfeasance, but critics often downplay the commitment of North Vietnamese and Vietcong insurgency leaders to the military struggle. The battlefield mattered to the enemy. According to Lien-Hang Nguyen, Le Duan, the North Vietnamese Politburo First Secretary, "drew a significant lesson from the First Indochina War: diplomacy without military

45. Although the evidence does not conclusively indicate what Johnson expected to accomplish in Honolulu, the president recalled coming back from the conference "refreshed and confident." However, his public comments upon returning - noting that the "road ahead may be long and may difficult" - suggest he did not think victory was in reach. See Johnson, The Vantage Point, p. 245. Arthur Schlesinger, Jr., argued that U.S. leaders repeatedly believed victory attainable if only a modest additional effort was added to the war effort. Yet each vision of victory proved to be beyond their grasp, which is how the United States ended up fighting an unwinnable war and pursuing unreachable goals. See Arthur M. Schlesinger, Jr., The Bitter Heritage: Vietnam and American Democracy, 1941-1966 (New York: Houghton Mifflin, 1967). Daniel Ellsberg, on the other hand, took the position that the United States persisted in Vietnam not because victory seemed possible but because the situation was so bleak that all U.S. leaders could do was hang on in the hope that the war might be ended on favorable terms. See "The Quagmire Myth and the Stalemate Machine," Public Policy, Spring 1971, pp. 217-274.

46. The Pentagon Papers, Vol. 4, p. 315. On building a legitimate political system, see John C. Donnell and Charles A. Joiner, "South Vietnam: 'Struggle' Politics and the Bigger War," Asian Survey, Vol. 7, No. 1 (January 1967), p. 53. 
superiority should be avoided at all costs." ${ }^{\prime 47}$ By 1966 , Le Duan had prevailed over the cabinet members who wanted to pursue a negotiated settlement. Instead, Hanoi would support the Southern revolution, deploying main force units on the battlefield to annihilate the "puppet" South Vietnamese army. "In fighting the American troops," Le Duan noted, "we must try to select their weak points and situations where they are weak in order to annihilate them." General Nguyen Chi Thanh, commander of the Southern revolutionary forces, backed this aggressive military strategy. Doubting the allies possessed enough combat strength to offer battle and support pacification, Thanh insisted his forces not only harass U.S. and ARVN units but also conduct large-scale regimental attacks. Against technologically superior U.S. forces, such a strategy might prove costly, but it would maintain pressure on the United States while simultaneously wearing down the RVN. From MACV's perspective, the evidence in early 1966 suggested the enemy "was now looking toward a protracted and difficult war." ${ }^{38}$

Recognizing Hanoi's commitment to both the political and the military struggle, U.S. policymakers at Honolulu delineated for Westmoreland six goals they believed best supported the overarching aims of defeating the enemy and extending GVN dominion and control. Assistant Secretary of Defense John McNaughton and Assistant Secretary of State for East Asian and Pacific Affairs William Bundy drafted the formal memorandum. After laying out planned increases for allied troop strengths in the coming year, McNaughton and Bundy indicated these forces would expand their offensive operations against the enemy while providing "essential defense" of key political and population centers inside the RVN. Westmoreland's six benchmarks for success concluded the memorandum. First, MACV would increase to 60 percent the population living in secure areas, a 10 percent increase from current U.S. estimates. Next, the allies would increase the critical roads and railroads open for use from 20 percent to 50 percent. The third goal envisioned

47. Lien-Hang T. Nguyen, Hanoi's War: An International History of the War for Peace in Vietnam (Chapel Hill: University of North Carolina Press, 2012), p. 78. On Le Duan, see also Pierre Asselin, "Le Duan, the American War, and the Creation of an Independent Vietnamese State," The Journal of American-East Asian Relations, Vol. 10, No. 1/2 (Spring/Summer 2001), pp. 1-27.

48. Le Duan quoted in David W. P. Elliott, "Hanoi's Strategy in the Second Indochina War," in Jayne S. Werner and Luu Doan Huynh, eds., The Vietnam War: Vietnamese and American Perspectives (Armonk, NY: M. E. Sharpe, 1993), p. 82. On Thanh, see William J. Duiker, The Communist Road to Power, 2nd ed. (Boulder, CO: Westview Press, 1996), pp. 273-274. According to "USMACV Command History," p. 2: "MACV's estimate of enemy intentions was that they would attack in mass whenever they thought victory was possible. At the same time, they would continue terrorism, harassment, sabotage, propaganda, and small hit-and-run attacks aimed at controlling the population and blocking any significant gains in GVN nation-building." 
a 30 percent increase in the destruction of Vietcong and North Vietnamese Army base areas (to roughly 50 percent) within the confines of RVN borders. Without question, this first set of three goals revealed the influence of Defense Department systems analysts determined to validate a quantitative approach to wartime management in Southeast Asia. Whether MACV could be so precise in achieving these exact figures remained to be seen. ${ }^{49}$

McNaughton and Bundy, however, appreciated the president's larger aims at Honolulu and ensured the final three goals supported Johnson's intent of incorporating political and nonmilitary plans into the larger military strategy. The fourth goal thus charged Westmoreland with ensuring the "defense of all military bases, political and population centers and food-producing areas now under government control." The influence of contemporary army doctrine was clearly visible. Fifth, MACV would provide military security necessary for pacification of "high-priority" areas (left unclear in the original message) and increase the pacified population there by 235,000 . Finally, in what came to overshadow all other aspects of the Honolulu conference, Westmoreland was to "attrite, by year's end," Vietcong and North Vietnamese army "forces at a rate at least as high as their capacity to put men in the field." ${ }^{50}$ Critics ever since have disparaged the MACV commander for pursuing, at all costs, this unattainable "crossover point" while ignoring the imperatives of populationcentric counterinsurgency. Yet Westmoreland had already established a comprehensive strategy that entailed much more than simply killing the enemy. His mid-1965 concept of operations and subsequent directives consistently spoke of coordinating nonmilitary and political efforts with larger military aims, and the McNaughton-Bundy memorandum did little more than direct Westmoreland to proceed as planned. ${ }^{51}$

This way forward held potential pitfalls, however. Westmoreland recalled that the "goals were optimistic, but I agreed they were good objectives to shoot for. I fully concurred with the establishment of goals, not so much for us as for

49. McNaughton memorandum, 10 February 1966, in FRUS, 1964-1968, Vol. IV, pp. 216-217; Davidson, Vietnam at War, p. 358; and Graham A. Cosmas, MACV: The Joint Command in the Years of Escalation, 1962-1967 (Washington, DC: CMH, 2006), p. 257. Westmoreland recalled in his memoirs: "Statistics were, admittedly, an imperfect gauge of progress, yet in the absence of conventional front lines, how else to measure it?" See Westmoreland, A Soldier Reports, p. 332.

50. Johnson-Nehru conversation, 10 February 1966, in FRUS, 1964-1968, Vol. IV, p. 218. John Prados discusses the "attrition strategy" coming out of the Honolulu conference in "American Strategy in the Vietnam War," in David L. Anderson, ed., The Columbia History of the Vietnam War (New York: Columbia University Press, 2011), p. 251.

51. Westmoreland, A Soldier Reports, p. 195. Exemplifying a critical appraisal of Westmoreland's strategy, focusing on organizational culture, is Andrew F. Krepinevich, Jr., The Army and Vietnam (Baltimore, MD: Johns Hopkins University Press, 1986). 
the South Vietnamese- to stimulate them." Therein lay crucial assumptions imperiling the entire U.S. effort in Vietnam. Senior U.S. military leaders and embassy officials could do no more than "urge" the Saigon government to implement the goals outlined at Honolulu. Even if Thieu and Ky were more compliant than Diem had been, they were still their own men. Despite being cognizant of the worth of U.S. aid and support, they were wary of Western influence while guiding a social revolution inside the RVN. Moreover, factors outside U.S. influence were already undercutting allied plans. One week after the conference ended, U.S. Ambassador Henry Cabot Lodge informed President Johnson that the "economic situation overall has become critical during the last two months," and South Vietnamese army desertion rates "continue to be unsatisfactory." 52 Finally, questions lingered over basic definitions. In March, Lodge, suggesting that setting goals and working to achieve them by a specific date was "not the traditional Vietnamese way," found it necessary to ask the president "to define exactly what we mean by pacification." For his part, Westmoreland later expressed regret in formalizing the term "search and destroy," even though the goals established in Honolulu "could not be achieved without such tactics." ${ }^{\text {3 }}$

Johnson raised few, if any, of these impending problems during the conference's final public pronouncements. In a joint statement with Thieu and $\mathrm{Ky}$, the president emphasized construction programs in an "effort to build democracy in the rural areas-an effort as important as the military battle itself." Offering short commentary on military operations, allied leaders instead spoke in familiar New Deal language about the need to intensify health and education programs and to bolster production output and rural electrification. The 8 February Declaration of Honolulu put forth similar themes. The allies dedicated themselves to the "eradication of social injustice," to establishing a "stable, viable economy," and to defeating those "illegally fighting" on South Vietnamese soil. ${ }^{54}$ The lofty rhetoric of free self-government and social revolutions, however, failed to convince many journalists back home. One day

52. Westmoreland, interview by Miles, p. 10; and Lodge memorandum, 16 February 1966, in FRUS, 1964-1968, Vol. IV, pp. 223-226. For a view of the U.S. embassy dealing with the "problem of intragovernmental conflict" in Saigon, see Richard Critchfield, "Lessons of Vietnam," The Annals of the American Academy of Political and Social Science, Vol. 380 (November 1968), pp. 125-134.

53. The Pentagon Papers, Vol. 2, p. 550; and W. Scott Thompson and Donaldson D. Frizzell, eds., The Lessons of Vietnam (New York: Crane, Russak, 1977), p. 64. Richard A. Hunt discusses the origins of the term "pacification" in what remains one of the best overall works on the subject, Pacification: The American Struggle for Vietnam's Hearts and Minds (Boulder, CO: Westview Press, 1995), p. 11.

54. Joint statement in Johnson, Public Papers, pp. 152-153; and Honolulu Conference Materials, February 1966, in Folder 4, Box 6, Douglas Pike Collection: Unit 02-Military Operations, TTUVA. 
after the allied declaration, The New York Times suggested the conference "left confusion in its wake, with more questions raised than answered." Stanley Karnow, writing in The Washington Post, claimed the "earnest assertions, pious hopes and brave statements" were more aims than solutions. Finally, the influential Walter Lippman was convinced that Johnson was misreading history, his "hot and unexamined generalities ... a moral commitment to endless crusading in all the continents." 55

Returning to Washington, an outwardly confident Johnson told reporters the road ahead would be difficult but that the allies would prevail in their batthe against aggression. The optimism surrounding the president's homecoming proved short-lived. The day of the Honolulu declaration, retired Lieutenant General James M. Gavin testified before the Senate Foreign Relations Committee, questioning the efficacy of Johnson's Vietnam policy. The former commander of the 82nd Airborne Division suspected that escalation in Southeast Asia was beginning "to hurt our world strategic position." Two days later, George Kennan echoed Gavin's concerns, declaring that even if "South Vietnam was controlled exclusively by the Viet Cong, while regrettable and no doubt morally unwarranted, [it] would not present ... dangers great enough to justify our direct military intervention." ${ }^{56}$ (Perhaps in response to the Fulbright hearings, Harris and Gallup public opinion polls in February revealed declining confidence in Johnson's handling of the war. $)^{57}$ These public challenges to U.S. foreign policy seemed all the more prescient when antigovernment demonstrations erupted in the northern provinces of South Vietnam during the first weeks of March. By late spring, the non-Communist demonstrators appeared to be on the verge of instigating an outright civil war. ${ }^{58}$ If Johnson had intended for the Honolulu conference to calm dissent and mark a

55. "Questions after Honolulu ...," The New York Times, 9 February 1966, p. 38; Stanley Karnow, "Conference Mixes Hopes and Hazards," The Washington Post, 9 February 1966, p. A1; and Walter Lippman, "President's Vietnam Talk Seems to Show a Misreading of History," Los Angeles Times, 9 February 1966, p. A5. See also Foreign Reaction to the Honolulu Conference, 10 February 1966, in Folder 3, Box 4, Larry Berman Collection (Presidential Archives Research), TTUVA. French journalist Jean Lacoutre argued that "the Honolulu meeting exposed the nearly total failure of a great Western power to understand public opinion in a small country, where feelings of oppression and resentment have been smoldering for years." Quoted in Gibbons, The U.S. Government and the Vietnam War, p. 233.

56. "Vietnam Policy-Testimony at the Committee Hearings," Congressional Digest, Vol. 45, No. 4 (April 1966), pp. 107-108. Johnson's homecoming remarks are from Johnson, The Vantage Point, p. 245. John Prados suggests the hearings "legitimized opposition and helped lay the foundation for dissenters." See Prados, Vietnam, p. 166.

57. Gibbons, The U.S. Government and the Vietnam War, p. 175.

58. Cosmas, The Joint Chiefs of Staff, pp. 445-446. 
"new departure," he clearly had misread the political landscapes both at home and abroad. 59

Emphasis on the political crisis in South Vietnam and the growing dissatisfaction at home, however, should not reinforce false narratives that the February summit was "essentially a public relations exercise." Nor should the final goal outlined by McNaughton and Bundy (to attrite enemy forces at a substantial rate) be seen as corroboration of shallow claims that Westmoreland and senior military officials yearned only to reach an elusive "crossover point" to win the war. ${ }^{60}$ Scholars should take Johnson at his word when he said the allies were trying to defeat not only aggression but also "social misery." ${ }^{61}$ Perhaps questioning the president's sincerity is misplaced when considering his proclamation that "We are trying to establish a stable democratic government, and we are searching for an honorable and just peace." ${ }^{62}$ The failures of the Honolulu conference arguably lay not in missed opportunities for peace or a narrow U.S. military strategy. ${ }^{63}$ Rather, the Hawaii summit exposed a naïve U.S. vision of South Vietnam out of step with the local conditions of a society long at war over fundamental issues of identity and nationalism in the modern era. Westmoreland had to match Johnson's soaring rhetoric to the political and military realities of South Vietnam.

\section{The Problems of Implementation}

MACV's commander returned to Saigon with the president's encouragement-a personal telegram from Johnson on 12 February noted, "we are on the right track" — and high expectations for "real progress" in the war on social misery. Westmoreland replied the following day. "Be assured we shall continue to press forward on the military front. Further, I shall

59. Dallek, Flawed Giant, p. 355. On the antiwar movement in 1966, see Charles DeBenedetti with Charles Chatfield, An American Ordeal: The Antiwar Movement of the Vietnam Era (Syracuse, NY: Syracuse University Press, 1990), pp. 141-167.

60. Thies, When Governments Collide, p. 336; and Jeffrey Record, Beating Goliath: Why Insurgencies Win (Washington, DC: Potomac Books, 2007), p. 121. For a discussion of Hanoi's forces also attempting to "attrite their enemy in many fields," see BDM Corporation, "A Study of Strategic Lessons Learned in Vietnam," Vol. 6: "Conduct of the War," General Holdings, in MHI, pp. 3-27-3-28.

61. Johnson, Public Papers, p. 223; and Robert Topmiller, "A Missed Opportunity for Peace in Vietnam-1966,” Peace \& Change, Vol. 27, No. 1 (January 2002), pp. 59-96.

62. Questioning military strategy in James M. Gavin, “A Soldier's Doubts,” Harper's, February 1966, pp. 115-116.

63. For a response, see Joseph Alsop, "Vietnam Coastal Enclave Strategy Could Mean Many Dien Bien Phus," Los Angeles Times, 9 February 1966, p. A5. 
support in full measure within the capabilities of my command the important and essential non-military programs of the mission." ${ }^{64}$ One week later, Westmoreland held a command conference at the 5th Special Forces Group headquarters in Nha Trang. His opening remarks concentrated on Honolulu, which he had found productive thanks to the candid discussion with Johnson and the promise of additional resources. After a lengthy dialogue on logistical shortfalls and future troop buildups, Westmoreland turned to the South Vietnamese economy and the political implications if Saigon's leaders could not control the rampant inflation threatening to undermine the war effort. Emphasizing his "continuing concern regarding the identification of the Viet Cong [political] infrastructure," the general then discussed GVN rural construction plans and his intent to "do everything we can to support ... this very important program." Throughout, the military effort interlaced this wide-ranging conversation, the conference itself suggesting that Westmoreland appreciated much more than battlefield tactics and troop deployment schedules. $^{65}$

In fact, the allied campaign plan for 1966, promulgated by the MACV staff on 31 December 1965, underscored how well Westmoreland's operational concept accorded with the strategic goals outlined in Hawaii. (By preceding the conference, the publication date also raises doubt over the general's claims that the Honolulu summit "dictated subsequent strategy and tactics of the war.") According to the MACV command history, the "basic objectives of the campaign for 1966 were to clear, secure, and assist in the economic development of the heavily populated areas around Saigon, in the Mekong delta, and in selected portions of the coastal plain." ${ }^{166}$ Concurrently, U.S. troops would defend outlying political centers through search-and-destroy operations against enemy main force units. Westmoreland intended these offensives to facilitate the South Vietnamese forces' defense of governmental centers and rice-producing areas, providing a shield behind which pacification

64. Johnson's telegram in The Pentagon Papers, Vol. 2, p. 561. Westmoreland's response in Cable, 13 February 1966, in Folder 4, Box 4, Larry Berman Collection (Presidential Archives Research), TTUVA. On the aftermath of the conference, see Robert Buzzanco, Masters of War: Military Dissent and Politics in the Vietnam Era (Cambridge, UK: Cambridge University Press, 1996), pp. 256-257. Westmoreland did "not recall any dissent that was made" over MACV's strategy at the time. A Soldier Reports, p. 256.

65. See MACV Commander's Conference, 20 February 1966, in Counter VCI Folder, Historian's Files, CMH. For a discussion on the U.S. Central Intelligence Agency's parallel attempts to undermine the insurgency's political infrastructure, see Thomas L. Ahern, Jr., Vietnam Declassified: The CIA and Counterinsurgency (Lexington, KY: University Press of Kentucky, 2010).

66. Westmoreland in Thompson and Frizzell, The Lessons of Vietnam, p. 11; and "USMACV Command History," pp. 340-341. 
programs could take root. A host of supporting tasks, complementing the goals laid out by McNaughton and Bundy, served to advance MACV's campaign plan-defending major base areas, opening and securing main roads, providing security for the expansion of GVN control, and denying the enemy rice by protecting harvests and capturing caches in enemy storage dumps. Concerned about troop indoctrination, Westmoreland also directed the publication of a "ready reference" pamphlet on South Vietnam defining the "twofold" mission as supporting the GVN against Communist aggression and assisting in the development of the country. ${ }^{67}$

Military operations also remained a major part of MACV's strategic approach. Yet battle served a larger purpose in Westmoreland's mind; it was not simply a tool for the attrition of enemy forces. In reviewing his concept for 1966, the general noted that monsoon-season "offensive tactical operations" were intended to force the enemy "to fight under conditions of our choosing," thus freeing a greater number of allied troops for area security and revolutionary development support missions. ${ }^{68}$ However, MACV never realized these ideals. Enemy forces, especially insurgents conducting raids and ambushes, held the tactical initiative throughout much of the year, and the threat of NVA main force units-North Vietnamese infiltration remained high in 1966precluded greater attention to revolutionary development. Even as the United States grappled with the problem of balancing military and nonmilitary efforts, the South Vietnamese were contending with their own troubles. The March demonstrations now included not only student protestors but ARVN soldiers. Prime Minister Ky blamed much of the civil unrest on a "militant Buddhist faction," but larger issues were clearly at play. Protesters demanded the creation of a national assembly, general elections, and an end to corruption in the general officer corps. Ky, aware of rising discontent against the military junta, saw "no viable democratic civilian alternative." ${ }^{69}$ If MACV was to move forward in accomplishing the goals delineated in Honolulu, it would do so from a shaky political foundation.

The nonmilitary aspects of the conference goals proved exceedingly difficult not only to achieve but even simply to measure. On the day of the

67. MACV Office of Information, "Ready Reference Facts on South Vietnam," n.d., in Box 3, Joseph A. McChristian Papers, MHI; and Concept of Military Operations, 26 August 1966, in Box 6, Paul L. Miles Papers, MHI, p. 2. See also Sharp and Westmoreland, Report on the War in Vietnam, p. 113. 68. Concept of Military Operations, 26 August 1966, p. 2. On difficulties measuring progress in the aftermath of Honolulu, see "USMACV Command History," pp. 541-542.

69. Ky, Buddha's Child, pp. 198-199. For an assessment agreeing with Ky, see Mark Moyar, "Political Monks: The Militant Buddhist Movement during the Vietnam War," Modern Asian Studies, Vol. 38, No. 4 (October 2004), pp. 749-784. 
Honolulu declaration, The Christian Science Monitor reported that less than one sixth of South Vietnam was "sufficiently free" of Vietcong influence and "much of that is insecure."70 At Hawaii, however, the U.S. delegation estimated 50 percent of the population was living in secure areas. Westmoreland might be charged with raising nationwide security by 10 percent, but merely approximating a baseline figure for who actually was "secure" generated wildly contradictory numbers. Moreover, the expansion of security came with a price. Westmoreland saw "no way to separate security considerations from pacification operations," yet MACV's concept relied on South Vietnamese forces accomplishing the latter. ${ }^{71}$ If U.S. troops succeeded in clearing national priority areas for their ARVN counterparts to hold, then the Saigon government would require additional troops to extend GVN influence into those recently cleared areas. This, according to the MACV command history, "presented a dilemma." Regional and popular forces, akin to local militias, constituted the bulk of forces assigned holding duties, but they were "far down in priority for training, equipment, and leadership, which resulted in marginal or unsatisfactory ratings in almost every category of their activities." Though unfair given the challenges local militia troops faced, Komer's complaint that the "civil side has to work through a weak and apathetic GVN" demonstrated mounting U.S. frustrations even at this relatively early stage of the war. ${ }^{72}$

Nonetheless, key questions remained. What did "secure" really mean? What indices accurately measured progress toward an objective that defied easy explication? Should the allies assess physical security of the rural population or attitudes on political stability inside Saigon? Surely, how secure one felt mattered. Valid measurements of security and the relationship of such measurements to development programs proved difficult to formulate, however. MACV found that despite positive reports from the field, many "local officials had a tendency to accept substandard construction and security" to meet deadlines. So unstable (and thus insecure?) had the revolting northern provinces become in May that Marine General Lewis Walt had to threaten to shoot down South Vietnamese air force jets that were planning an attack

70. Saville R. Davis, "Doubts Cloud Vietnam Reforms," The Christian Science Monitor, 8 February 1966, p. 1.

71. Sharp and Westmoreland, Report on the War in Vietnam, p. 119. For a South Vietnamese perspective, see Tran Dinh Tho, "Pacification," in Lewis Sorley, ed., The Vietnam War: An Assessment by South Vietnam's Generals (Lubbock: Texas Tech University Press, 2010), pp. 215-264.

72. "USMACV Command History," p. 108; and Komer to Johnson, 9 May 1966, in FRUS, $1964-$ 1968, Vol. IV, p. 374. On Komer's view of the issue as a "management problem," see Frank L. Jones, Blowtorch: Robert Komer, Vietnam, and American Cold War Strategy (Annapolis, MD: Naval Institute Press, 2013), p. 101. 
on dissident ARVN units in their compounds. ${ }^{73}$ Yet the precision of MACV's quantitative assessments apparently prevailed over this uncertain landscape. In early July, Westmoreland reported that "secured areas had increased by 2.4 percent." Soldiers on the ground likely would have questioned the exactitude of MACV's reporting system. The tactical fighting proved far more confusing. One soldier in the 25th Infantry Division recalled that the enemy "always hit us where we were weakest, always decided when, where, and how to fight us and when to break away and melt into the local populace or go down the tunnels." U.S. correspondents found a war-weary population tiring of constant reform promises while seeing few improvements in countryside security ${ }^{74}$

Complications in opening up critical roadways contributed to larger issues with winning the rural population's allegiance. Concerned about keeping the enemy off balance and preventing main force units from striking at will, Westmoreland often prioritized military traffic on key lines of communication accessing South Vietnam's interior. While tactically sensible, the preemption of port space, rail lines, and waterways for military operations forced the civil side, in Komer's words, to make do "with what is left." In June, Komer painted a fuller picture for Johnson by outlining what he called the "problem of scale." Convinced the allies were not moving fast enough in the civil arena, the president's special assistant offered some "crude comparisons" for instruction. "We are spending perhaps $\$ 15-18$ billion on the military side and only $\$ 700-800$ million on the civil side. We've deployed about 300,000 troops compared to about 3,000 civilians." South Vietnamese numbers appeared comparable. ${ }^{75}$ Although Komer's analysis was far from comprehensive, it suggested deeper issues with the allied approach, in particular that the war effort was unbalanced. Hanoi's commitment to offensive operations inside the RVN necessitated a military response, yet that response increasingly pulled attention and resources away from the developmental side of the struggle. Fighting aggression was transcending the fight against social misery.

73. "USMACV Command History," pp. 543-544; and Walt in The Pentagon Papers, Vol. 2, p. 375. See also Lewis W. Walt, Strange War, Strange Strategy: A General's Report on Vietnam (New York: Funk \& Wagnalls, 1970), pp. 113-124.

74. Eric M. Bergerud, Red Thunder, Tropic Lightning: The World of a Combat Division in Vietnam (Boulder, CO: Westview Press, 1993), p. 253; and "War-Weary Vietnamese Tire of Reform Promises," The Christian Science Monitor, 12 February 1966, p. 5.

75. Komer to Johnson, 9 May 1966, 14 June 1966, in FRUS, 1964-1968, Vol. IV, pp. 374, 420; and "USMACV Command History," p. 347. On realizing economic goals, see Updated Report on Status of Implementation-Honolulu Agreements, 30-31 March 1966, in Folder 12, Box 4, Larry Berman Collection (Presidential Archives Research), TTUVA. 
Arguably, the very goals outlined at Honolulu produced this imbalance. The destruction of enemy base areas, for instance, was at odds with opening critical roads for economic use. During an April press briefing, Westmoreland estimated that twelve North Vietnamese army and thirteen Vietcong regiments were inside the RVN. When accounting for "guerrillas, cadre and logistic support troops," MACV approximated a total of 250,000 enemy troops in country. ${ }^{76}$ If security preceded development as current doctrine prescribed, Westmoreland deemed it essential that allied forces strike enemy base areas and start wearing down the forces there. The matter became all the more important given political constraints forbidding MACV's commander from sending troops into Cambodia and Laos to disrupt enemy sanctuaries sustaining the military effort in South Vietnam. In the process, though, military traffic took precedence on roads designated as key economic routes. Worse, attacking an enemy that was in some places tightly interwoven into the fabric of South Vietnamese society meant putting noncombatants at risk. Although MACV officers genuinely attempted to limit civilian casualties, the war unfolding around them became all the more horrific once U.S. units began bringing vast amounts of firepower to bear. Mohr, reporting in June on the use of "cluster bomb units," found the canisters of 800 bomblets, some spewing both napalm and steel pellets, to be as "stupendous" as they were "terrifying." 77

No doubt many South Vietnamese civilians, caught between U.S. firepower and VC political intimidation, agreed with Mohr's assessment. Although some among the rural population sincerely backed the insurgent cause, the contest over the people's loyalty reflected, in two contemporary observers' words, "the undeveloped state of South Vietnamese political consensus." Here, in the political arena, U.S. forces faced their greatest challenges. MACV understood clearly the Saigon government's efforts to "regain the confidence and loyalty of the rural population" and that it "must remain a GVN

76. Westmoreland Briefing, 30 April 1966, in Folder 3, Box 6, Douglas Pike Collection: Unit 01Assessment and Strategy, TTUVA, p. 5. On attacking base areas, see MACV Monthly Evaluation Report, June 1966, in MHI, p. 3. Edwin Moïse tackles the problem of Westmoreland's command (under)estimating enemy strength in the years before the 1968 Tet offensive in The Myths of Tet: The Most Misunderstood Event of the Vietnam War (Lawrence, KS: University Press of Kansas, 2017), esp. chs. 2-3.

77. Charles Mohr, "Vast U.S. Firepower Arrayed in Vietnam against Guerrillas," The New York Times, 28 June 1966, p. 2. Westmoreland's command stressed that a "conscious effort was made to minimize noncombatant casualties." See MACV, "USMACV Command History," 196t, in NARA, p. 161. For a contrasting view depicting civilian suffering as the norm and war crimes a natural outgrowth of U.S. command policies, see Nick Turse, Kill Anything That Moves: The Real American War in Vietnam (New York: Metropolitan Books, 2013). 
responsibility, with the U.S. in an unobtrusive advisory and support role." ${ }^{\text {78 }}$ U.S. troops, however, were anything but unobtrusive. When an April status report on the Honolulu conference goals found the prospects for local village elections "still in doubt," pressures mounted within the U.S. mission to coerce Thieu and Ky's government into action. Moreover, the U.S. logistical and financial support to the GVN's Revolutionary Development Cadre, along with U.S. advisers coordinating related security efforts, undercut the narrative of pacification being a South Vietnamese endeavor. ${ }^{79}$

As with "security," the definition of "pacification" remained contested. One week after the Hawaii summit, the Los Angeles Times suggested "pacification" was a word of "changing meanings, and sometimes of no real meaning at all, except for the peasant's desire to live at peace, grow and market his rice without double taxation or fear of Communist confiscation." Ky spoke in terms of a social revolution to create a "new life," but senior U.S. officials emphasized the relationship between Saigon and the rural population. At Honolulu, Johnson urged his counterparts to "get closer to the people" and recommended that Ky "spend more time in the countryside playing the role of a politician rather than a general." ${ }^{80}$ One month later, Colonel John H. Cushman published a topical essay in Army magazine. An adviser with the ARVN 21st Infantry Division, Cushman believed he had developed a workable concept that, if replicated nationwide, might turn the war around. But he acknowledged that success depended on the people. A series of "ifs" followed. If only dedicated South Vietnamese could be found to become "good district chiefs." If only the GVN could develop a political organization equally as effective as the Vietcong. If only Saigon could regain control of the countryside. Cushman's essay articulated, powerfully but likely unintentionally, the limits of U.S. influence in arousing a genuine commitment from the South Vietnamese people for their government-if, in fact, that is what "pacification" meant. ${ }^{81}$

78. Donnell and Joiner, "South Vietnam," p. 64; and "Operational Guidelines for Advisory Support of Revolutionary Development Cadre," 13 June 1966, in Revolutionary Development Folder 2, Box 1, Richard M. Lee Papers, MHI, p. 2.

79. Honolulu Conference, Status of Activities, 7 April 1966, in Folder 11, Box 4, Larry Berman Collection (Presidential Archives Research), TTUVA, p. 2. Operational Guidelines, in MHI, p. 3. On problems with local South Vietnamese regional and popular forces implementing pacification plans, see Andrew Wiest, Vietnam's Forgotten Army: Heroism and Betrayal in the ARVN (New York: New York University Press, 2008), pp. 74-75.

80. "Vietnam Pacification and What it Means," Los Angeles Times, 13 February 1966, p. L4. "Presidential Decisions," TTUVA, p. 23. Westmoreland, interview by Miles, p. 10.

81. John H. Cushman, "Pacification: Concepts Developed in the Field by the RVN 21st Infantry Division," Army, Vol. 16, No. 3 (March 1966), pp. 28-29. Jamieson, Understanding Vietnam, p. 228. 
Cushman's emphasis on control hinted at further problems with the U.S. goals outlined in Honolulu. One week before the conference, The Washington Star reported that the Saigon government controlled barely one-fourth of the country. By the end of 1966, MACV confirmed only a 5 percent increase of the population living in secure areas. (Senior officials often conflated the terms "control" and "security" without a full understanding of either.) Yet even these figures appeared dubious. Komer's midyear summary to the president conceded: "We don't really know enough about what's happening at the cutting edge down in the village or even district." 82 The admission was telling. Undertaking the task of nation-building, U.S. officials quickly found that providing the South Vietnamese with economic and social benefits was failing to reap rewards in loyalty from or influence over the rural population. Even though U.S. officials recognized the essential role played by the ARVN in expanding areas under governmental control, they equally blamed thei South Vietnamese troops for failing to measure up. One late-year report offered a laundry list of U.S. complaints about the ARVN: "poor leadership, harshness toward the civilian population, corruption, lack of aggressiveness." ${ }^{83}$ If the U.S. mission in Vietnam hoped to expand GVN control, relying on the local army to do so was proving disappointing.

So, too, were efforts in battlefield attrition of enemy forces. In April 1966, MACV reported that despite substantial losses, enemy forces inside South Vietnam continued to increase. Insurgent forces in particular avoided significant contact with the technologically superior U.S. troops, whose firepower too often demolished the countryside. One woman compared a U.S. attack to clear her village of Vietcong to "a raging elephant stomping on red ants too far down in their holes to feel the blows." ${ }^{84}$ Westmoreland complained

82. John T. Wheeler, "Only a Fourth of South Viet Nam Is under Control of Saigon Regime," The Washington Star, 25 January 1966, p. A4. On the problems of defining control, see Bernard B. Fall, "Insurgency Indicators," Military Review, Vol. XLVI, No. 4 (April 1966), pp. 3-11; and Komer to Johnson, 14 June 1966, FRUS, 1964-1968, Vol. IV, p. 423. Security figures are from Cosmas, The Joint Chiefs of Staff, p. 461.

83. R. W. Apple, Jr., “Saigon's 'Army: A U.S. Challenge," New York Times, 12 December 1966, p. 7. For an earlier report, see John Hughes, "Prospects Grow Dim for Honolulu conference," The Christian Science Monitor, 20 April 1966, p. A1. On nation-building, see "USMACV Command History," in NARA, p. 348. On loyalty and influence, see Gibbons, The U.S. Government and the Vietnam War, p. 65; and Robert M. Montague, "Pacification: The Overall Strategy in South Vietnam," Student Essay, U.S. Army War College, 22 April 1966, in Robert M. Montague Papers, Box 1, MHI, p. 5.

84. MACV Monthly Evaluation Report, April 1966, in MHI, p. 2. Villager quoted in Robert D. Schulzinger, A Time for War: The United States and Vietnam, 1941-1975 (New York: Oxford University Press, 1997), p. 193. On dealing with infiltration problems, see Westmoreland Briefing, 30 April 1966, p. 13. 
that less aggressive ARVN units were faring no better. Yet larger questions surrounded MACV's goal for attrition. What was the North's capacity to put men in the field? How could the U.S. Army assess whether its military operations were influencing Hanoi's will? Perhaps most important, MACV admitted that despite gains in coping with the enemy's main force units, "the communist political infrastructure retained its strength and vigor" throughout South Vietnam. In this sense, Hanoi's capacity to put men in the field, estimated at 75,000-100,000 annually, may have missed the point. Containing the infiltration of NVA units into the South may have mattered only if the GVN was making comparable progress in the political struggle for the population's loyalty. ${ }^{85}$

That the enemy's political infrastructure counted as much as its military strength suggested a multifaceted problem in balancing the competing demands of nation-building during a war. As early as February, Hanson Baldwin had reported in The New York Times that the nation's armed forces were "spread dangerously thin in Vietnam and elsewhere." With midsummer assessments characterizing the ARVN as the "weak link in the chain," it appeared that U.S. troops would be called on for even greater sacrifices if the goals outlined in Honolulu were to be achieved by year's end. ${ }^{86}$ But progress, so difficult to measure in a war without fronts, proved hard to establish. As 1967 opened, MACV could only report on the limitations of past "yardsticks" for evaluating progress, admitting the "limitations of past and present systems." ${ }^{87}$ Given these shortcomings, the Honolulu goals quietly faded from public debate. Although the framework (without the precise quantification) continued to shape Westmoreland's campaign plans over the next two years, U.S. policymakers confronted in early 1967 the prospects of an increasingly stalemated war. None of the Honolulu goals had been fully achieved.

85. "MACV Command History," 1966, p. 350; Westmoreland to Wheeler, 14 May 1966, in Folder 9 , Box 3, Series I Official Correspondence, WC Westmoreland Collection, MHI; and Carver to Helms, 7 July 1966, in FRUS, 1964-1968, Vol. IV, p. 489. On enemy troop increases, see Charles Mohr, "Foe Put at 282,000 in South Vietnam," The New York Times, 10 August 1966, p. 1.

86. Hanson W. Baldwin, "U.S. Combat Forces Spread Thin," The New York Times, 21 February 1966, p. 1; and Komer to Johnson, 1 July 1966, in FRUS, 1964-1968, Vol. IV, p. 475. For an evaluation of the internal problems beleaguering the South Vietnamese army, many outside the influence of U.S. advisers, see Robert K. Brigham, ARVN: Life and Death in the South Vietnamese Army (Lawrence, KS: University Press of Kansas, 2006).

87. "USMACV Command History," p. 540; and Lodge's October assessment, in Office of Secy, Joint Staff, Box 5, RG 472, NARA, p. 545. On the measurement problems in this type of war, see Gregory A. Daddis, No Sure Victory: Measuring U.S. Army Effectiveness and Progress in the Vietnam War (New York: Oxford University Press, 2011). 


\section{Impractical Means, Improbable Ends}

In August 1966, Westmoreland was already turning his attention to the 1967 campaign plan. Hoping to promote a better understanding of his concepts, he sent a cable to Pacific Command, with copies to the White House, outlining the allied effort in South Vietnam. Although the enemy had taken a beating during the year, he nonetheless remained "determined." Thus, Westmoreland's strategy for the coming year would "be one of a general offensive with maximum practical support to area and population security in further support of revolutionary development." The enemy threat, at least as perceived by MACV, continued to shape allied concepts of operation. So, too, did the sequential approach to nation-building advocated by army doctrine and contemporary military theory. Westmoreland seemed adamant on this point. "The essential tasks of revolutionary development and nation building," he argued, "cannot be accomplished if enemy main forces can gain access to the population centers and destroy our efforts." With the additional U.S. forces approved at Honolulu, MACV foresaw the ARVN shifting more of its weight to supporting nonmilitary programs. The concept for 1967 accordingly mirrored the language used at Honolulu. Westmoreland spoke about defending base areas, opening railroads, securing the population, and reinforcing offensive operations. If the conference goals were not achieved in 1966, they would remain largely in place the following year. ${ }^{88}$

The Honolulu conference thus left a lasting legacy on U.S. strategy. MACV took seriously Johnson's call for a war on social misery and faithfully integrated nonmilitary programs into its campaign plans. Allied military operations often caused the very misery Johnson hoped to alleviate, but after the Honolulu conference the U.S. mission in Vietnam took great strides in expanding revolutionary development. In November 1966, the U.S. ambassador announced the creation of the Office of Civil Operations, and Westmoreland named a brigadier general as his special assistant for pacification. Six months later the president approved the formation of a larger organization, Civil Operations and Revolutionary Development Support (CORDS). Johnson named Komer, with full ambassadorial rank, as chief of CORDS and granted him wide leeway over nonmilitary programs. This expanded "organizational machinery for pacification," however, fostered only limited gains in

88. Concept of Military Operations in SVN, 26 August 1966, in Historian's Files, U.S. Strategy, Vietnam, 1965-76, CMH. To Southeast Asia specialist Bernard Fall, the conference goals were not achieved. "If the high-sounding principles of the Honolulu Declaration . . . were to be the gauge of accomplishment in the field of socio-economic development in Vietnam, then the past year will have proven a regrettable failure." Fall, "Vietnam," p. 12. 
revolutionary development over the coming years. ${ }^{89}$ Moreover, any progress made often went undetected by the U.S. public, who increasingly questioned the merits of what appeared a stalemated war.

The U.S. approach outlined at Honolulu was comprehensive. Perhaps because of that comprehensiveness, the U.S. effort in Vietnam faltered. Although officers grappled with the "complex interrelationships of military, economic, social, psychological, and political aspects" of the war, they failed to appreciate that their multiple goals often were working at cross-purposes. "Stimulating" aggressive military action and supporting civic action theoretically went hand in hand, but implementing both simultaneously proved impractical. ${ }^{90}$ More importantly, the Honolulu goals suggested that the U.S. delegation was overestimating its ability to dominate events inside South Vietnam. If success truly required a social revolution in the South—as Ky, and Diem before him, prescribed-it became increasingly clear after Honolulu that no U.S. personnel could harness that revolution for their own ends. This predicament should have been clearer given recent history. As Indochinese specialist Bernard Fall reminded readers, "the new pacification plans of the 1966 Honolulu Declaration echo an old French dilemma: how to promote real reforms while prosecuting a war and without making the government one supports look like a 'puppet." ${ }^{\prime 1}$ Few U.S. officials, however, questioned their country's capacity to incite a social revolution and build a democracy all while fighting a war against a determined enemy.

In 1971, Westmoreland, who by then was serving as the Army Chief of Staff, recalled in an interview that the "Honolulu Conference was a turning point in Johnson's conduct of the war." In Hawaii, the president "realized he was committed to war." That commitment, however, rested on unrealistic expectations and on a near blind faith in the U.S. government's power to influence local South Vietnamese realities. More circumspect policymakers questioned the prospects of motivating the people to support Saigon's government. As the Hawaii summit concluded, a senior official seemed pessimistic in achieving such lofty political goals. "I don't want to raise hopes that we

89. Organization in Herring, LBJ and Vietnam, p. 78; and Cooper et al., "The American Experience with Pacification in Vietnam," p. 225.

90. Montague, "Pacification," p. 5. On aggressive action and winning "hearts and minds," see "Tactical Standing Operating Procedure for Counterinsurgency Operations," Headquarters, 1st Brigade, 101st Division, 1 June 1966, in VNI Folder 17, CMH, p. I-1.

91. Bernard B. Fall, Viet-Nam Witness: 1953-66 (New York: Frederick A. Praeger, 1966), p. 342; and Bundy memorandum, 23 February 1966, p. 248. 
cannot justify." ${ }^{\prime 2}$ Here, arguably, the Honolulu conference offers the most useful perspective for evaluating more-current foreign policy problems. Power and prestige do not always translate into influence abroad, and exporting democracy in a time of war may be the most challenging mission assigned to U.S. armed forces. Few U.S. officials at Honolulu seemed to grasp the daunting challenges. ${ }^{93}$ Establishing strategic goals without fully considering the limits of one's power may be an exercise in counterproductive futility at best, or arrogant ineptitude at worst.

92. Westmoreland, interview by Miles, p. 7; Davis, "Doubts Cloud Vietnam Reforms"; and LTC James C. Swain, VNIT 30, in CMH, p. 13.

93. Lawrence E. Grinter, "Bargaining between Saigon and Washington: Dilemmas of Linkage Politics during War,” Orbis, Vol. 18, No. 3 (Fall 1974), p. 837. 